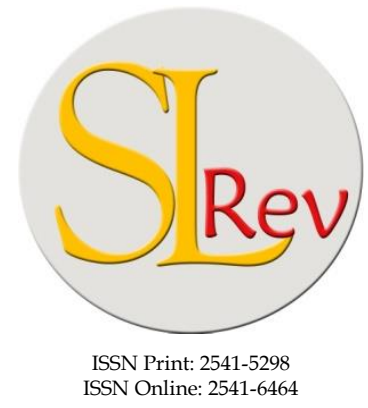

\section{The Issue of the Commercial Court Limited Competency in Settling the Commercial Disputes}

Editorial Office: Faculty of Law, Sriwijaya University, Jalan Srijaya Negara,

Palembang, South Sumatra 30139, Indonesia.

Phone: +62711-580063Fax: +62711-581179

E-mail: sriwijayalawreview@unsri.ac.id| sriwijayalawreview@gmail.com

Website: http://journal.fh.unsri.ac.id/index.php/sriwijayalawreview

\title{
Sobandi*
}

\begin{abstract}
The people's need for justice through a special court is perceived urgent from time to time. The Commercial Court is an ad-hoc court but its competency has affected the competency of other permanent courts that are already established. The problems need to be answered in this writing regarding the multifunction of Commercial Court. The objectives of the writing, inter alia, to examine the possibility of the Commercial Court has specific rules to restrain its competency. Consequently, there is a need to have a law that specifically limits the competence and the procedural law of the adhoc court. The Commercial Court often resolves bankruptcy disputes. It is also used as a solution for the Intellectual Property Rights (IPR) disputes which should be able to enter the criminal domain. It can also be used to solve the Islamic financing issues and other business issues that should be the realm of a permanent judicial institution. The existence of such a rule that limits the competency of the Commercial Court can be a way out of fulfilment of needs of the judiciary to reduce the overlap of court competency among the Indonesian judicial institutions.
\end{abstract}

Keywords: Commercial Court; Court Competency; Islamic Financing Issues; Intellectual Property Rights Disputes; Procedural Law.

\section{ARTICLE HISTORY:}

\section{DOI: 10.28946/sIrev.Vol3.Iss1.250.pp26-33}

Received: Oct 03, 2019;

Reviewed: Dec 10, 2018;

Accepted: Jan 19, 2019;

Published: Jan 31, 2019.

Ph.D Candidate, Faculty of Law, Universitas Sriwijaya, Head of District Court Depok, West Java.E-mail: ki.sobandi@gmail.com

\section{INTRODUCTION}

Judicial power, in the context of the Indonesian state, is the power of an independent state to hold a judiciary to uphold law and justice based on the ideology of Pancasila for the implementation of the rule of law in the Republic of Indonesia. The implementation of an independent judicial power for law enforcement and justice is carried out by a Supreme Court and the judiciary body under it, for example, the General Court, the Religious Court, Martial Court, and The State Administrative Court. ${ }^{1}$ All of these courts are as the foundation of the State Court System in Indonesia divided and separated based on their jurisdictions system. The Regulation Number 37 of 2004 Concerning Regulation of Bankruptcy and the Suspension of Obligation for Payment of Debts $^{2}$ stated in Article 300 that:

\footnotetext{
Article 25 the Regulation No. 48 of 2009 on the Judicial Power.

Hereinafter is cited as the Regulation No. 37 of 2004 or the Bankruptcy Law.
} 
1. The Court as referred to herein, besides examining and adjudicating the case on petition for declaration of bankruptcy and suspension of obligation for payment of debts, shall also be authorized to examine and adjudicate of other cases in the commercial aspect which shall be stipulated by law.

2. Establishment of Court as referred to in paragraph (1) shall be made gradually by virtue of the Presidential Decree, by taking into account need and preparedness of resources required.

The Article above may be assumed that the Commercial Court which is under the General Court has also the authority to adjudicate other commercial cases. The authority of the Court above is elaborated in Article 3 of the same Act as follows:

1. A decision on a bankruptcy petition and other related issues as intended by this Law shall be rendered by the Court having jurisdiction over the region in which the domicile of the Debtor is located.

2. In the event that the Debtor has left the territory of the Republic of Indonesia, the competent Court to render a decision on a bankruptcy petition is the Court having jurisdiction over the region where the last domicile of the Debtor was located.

3. In the event that the Debtor is a shareholder of a firm, the Court having jurisdiction over the region where the domicile of such firm is located shall also be competent to decide.

4. In the event that the Debtor does not have a domicile within the territory of the Republic of Indonesia but conducts his profession or business in the territory of the Republic of Indonesia, the compe- tent Court to decide is the Court having jurisdiction over the region where the domicile of the office from which the debtor conducts his profession or business is located.

5. In the event that the Debtor is a legal entity, the legal domicile thereof shall be as intended by its Articles of Association.

In other words, the Commercial Court granted an exclusive authority is authorized to examine all matters relating to the application of the Regulation No. 37 of 2004 on the Bankruptcy and the Delay in Debt Repayment Obligations, especially as what has been stipulated in the first and second chapters of the regulation above. ${ }^{3}$ Furthermore, the Commercial Court was first court established in accordance with Article 281 of the Regulation on Bankruptcy of the Commercial Court in the Central Jakarta District Court. And then based on the Presidential Decree No. 97 of 1999 four locations of Commercial Courts were established in Indonesia, such as the Semarang Commercial Court, the Surabaya Commercial Court, the Medan Commercial Court and the Makassar Commercial Court. In examining the case, the Commercial Court applies the civil procedural law ${ }^{4}$. It is important to know that the current Indonesian civil procedural law is the Herzien Inlandsch Reglement (HIR $)^{5}$ and the Rechtreglement voor de Buitengewesten (Rbg). ${ }^{6}$ Therefore, the Commercial Court

\footnotetext{
See Chapter One dealing with the General Provisions and the Second Chapter concerning the Bankruptcy, The Regulation No. 37 of 2004 on the Bankruptcy and the Delay in Debt Repayment Obligations (State Gazette No. 131 of 2004).

Article 299 of Law Number 37 of 2004.

HIR is an abbreviation of Herzien Inlandsch Reglement which is often translated as the Indonesian Updated Regulations, namely the procedural law in the civil court and criminal cases that apply on the islands of Java and Madura. This regulation applies in the era of the Dutch East Indies, listed in the State Gazette No. 16 of 1848 .

$\mathrm{RBG}$ is an abbreviation of the Rechtreglement voor de Buitengewesten which is often translated by the Regional Law of the Outer Region (outside Java Madura), namely the
} 
procedural law generally applies to district court procedural law, unless otherwise stipulated by the law. A commercial court examines and decides on a bankruptcy application or to postpone the obligation of a debt payer as follows:

1. Civil proceedings before the Commercial Court apply with writing or letters;

2. Obligations with Expert Assistance;

3. The Liberal-Individualist Model;

4. Simple proof;

5. Limited inspection time;

6. Decisions are immediate (UVB);

7. Arbitration Clause;

8. No Appeals are available.

Indonesia has 4 (four) judicial institutions consisting of General Court, Religion Court, Martial Court, and the State Administration Court. There is another special justice institution, namely the Commercial Court under the General Court. The existence of various judicial institutions in Indonesia shows that the Republic of Indonesia is a state of law. Article 1 paragraph (3) of the 1945 Constitution of the Republic of Indonesia expressly states that Indonesia is a rule of law. The intended legal state is a country that upholds the rule of law to uphold truth and justice and no power or authority is not accounted for.

The elaboration of the competencies includes the authority to examine issues related to Intellectual Property Rights (IPR), ${ }^{7}$ including the authority to examine brand disputes, patents, industrial designs, and integrated circuit layout designs. The creation of a Commercial Court is to provide for justice, legal certainty and benefits for the

procedural law that applies in the Civil Court and criminal cases in courts outside Java and Madura. Listed in State Gazette 1927 No. 227.

Herein after is cited as IPR community. For this reason, expanding the development of the Commercial Court will be based on these three points by looking at the existence of the Commercial Court at this time in relation to a court that decides bankruptcy cases / Delays in Debt Payment Obligations (DDPO/PKPU) and IPR.

The researchers are interested in discussing the limitations of the Commercial Court's competency because the bankruptcy arises from debts that cannot be fulfilled by creditors. However, the community mind-set and law enforcement often resolve it in the Commercial Court, which actually can be settled first in the District Court. Then the issue of IPR which can be categorized as a crime is settled through the Commercial Court. Not to mention if the banking or Islamic finance institution that is supposed to have a commercial dispute or bankruptcy should be settled in the Religious Court. The researchers are curious to find out clear boundaries of the authority of the Court. The problems raised in this paper refer to the question of whether the limited competency of the Commercial Court has may solve the disputes in the sector of the commercial. Further, what sort of limitation the Commercial Court may use to settle the commercial disputes.

\section{RESEARCH METHODS}

The collected data were primary, secondary, and tertiary data. The secondary data obtained from the library studies, such as legislation, legal, and textbooks. The primary data were collected through a direct interview with several judges of the Commercial Courts, lecturers teaching Commercial law, and the practitioners. The secondary data were collected from the law library, mostly dealing with the research topic. All collected 
data were analysed using descriptive qualitative method.

\section{FINDINGS}

Dealing with the effectiveness of the competency of the Commercial Court in settling the dispute in commerce, there are two findings that relevant to answer the question raised. Firstly, it is the issue of limited competency of the Commercial Court in the Settlement of Disputes in the Commercial Sector. Secondly, it is the formulation of limitation of the competency that the Commercial Court may apply in the commercial dispute settlement. Those findings will be explained as follows:

The issue of the Commercial Court limited competency in Settling Disputes in the Commercial Sector.

The idea of Law teachings (Cita Hukum) which in the Dutch term it is called the Idee des Recht consisting of three elements: legal certainty (rechtssicherkeit), justice (gerechtigkeit) and expediency (zweckmasigkeit). Gustav Radbruch is of the opinion that these three elements must exist in the enforcement of the law. Although the substance of bankruptcy in principle is still circles on the different meanings of a number of provisions, in reality the imposition of verdict of the Commercial Court often attracts the legal experts' attention for the application of the Regulation Number 37 of 2004 that has jeopardized the spirit of bankruptcy law as the principle of business sustainability. There are many argumentations conveyed by legal experts concerning the elements of bankruptcy (Article 2) and the simple evidence stipulated in Article 8 Paragraph (4) of the Regulation of 2004. Other weaknesses of bankruptcy law are that there is no minimum number of creditors and a minimum value of debt mentioned in that law as well as the absent of decency principle in the minimum value of the nominal debt. Not surprising that bankruptcy decisions are controversial. This condition is in opposition to the bankruptcy law as applied in Singapore, Hong Kong, and the United States which regulate the minimum creditors to be 12 or even more. ${ }^{8}$ Furthermore, Hamilton had made some comparison among the executive, legislative and judicial powers. Among these three bodies, the judicial body is the weakest one. The strongest one is the executive body as Hamilton mentioned its sword, the real power to carry out the decision and the legislature which has a purse, the budgetary rights. While the judiciary has nothing. Nevertheless, compared to the three bodies above, the real power is at the hand of the Supreme Court. Every decision it makes is obeyed by the president and his people. Even if it is returned to the fundamental basis of the state, there are at least two factors which are the source of court power. First, it is ethical demands. Even though the law does not regulate the obligations of state administrators to obey the judge's decision, the ethical demands are encouraged to be complied. The ethical demand arises from the awareness that the judge's decision is a law to be obeyed. Second, it is the trust in the integrity of the judge as an honest and impartial referee. Every judge's decision must be accepted as true.

To provide a sense of justice for the creditors of the property of the debtor which is used as a substitute for repayment of the loan to the creditor, then one of the government's efforts is to fix the legal system re-

\footnotetext{
Sumarmi, Perbandingan Sistem Hukum Kepailitan Antara Indonesia (Civil Law System) dengan Amerika Serikat (Common Law System), Medan: Fakultas Hukum Universitas Sumatra Utara, 2014, pp 9-11.
} 
garding the fulfilment of obligations carried out by the debtors to creditors by seeking a fair settlement, that is, by establishing Bankruptcy regulations that can be used quickly, fairly, openly and effectively, and in accordance with the current conditions. The official government legal institution that has the right to deal with bankruptcy cases according to the Bankruptcy Act is a court whose jurisdiction covers the area where the debtor is domiciled. The court according to the Bankruptcy Act is the Commercial Court.

The Commercial Court resolves the commercial disputes fast. In addition; it also solves various bankruptcy problems, such as verification, debt verification, actio pauli$a n a$, and so on. This is where there is sometimes a crossing with the competence of the Central Jakarta District Court in case of case hearings, including civil cases. Through the Bankruptcy Law, the absolute authority (absolute competence) of the General Court to examine bankruptcy requests is transferred to the Commercial Court. Herein, the commercial court has absolute competence in handling disputes in the business or commercial fields such as bankruptcy, delays in debt and IPR obligations. It cannot be denied that the legal approach to the economy has a purpose that does not merely distinguish between finding legal limitations, but seeing and occupying legal issues through legal and economic dimensions in economic ways and considerations. Economists have no reason to eliminate or override the existence and function of law.

\section{Concept of Limitation that can be applied} by the Commercial Court in Indonesia in the settlement of commercial disputes

The legalistic system adopted in Indonesia makes written law as the main source. Under this system, anybody may only be punished if there is a law governing it. In Latin term, it is acknowledged as principle nullumdelictumnoela poena sina previa lege poenali. The effectiveness of certain laws and regulations depend on many factors in its enforcement, such as the condition of the community which can make the law not fully enforced. For example, as one witness the enforcement of the Intellectual Property Rights (IPR), the public is not ready aware to spell it. Copyright protection, for instance, is something that not all Indonesians have the capacity to purchase the original product. Taxes and royalty paid to the creator make the price of the product expensive. Under this condition, not many people are able to purchase the original product. This loophole opens the possibility of other people to sell fake products which are available at the market. Although there have been enacted regulations on IPR, it does not deter the people to produce and buy fake products.

Actually, such good and correct regulations or law drafted should have met the following principle of a good and correct legislation which derives from the Dutch term called 'beginselen van behoorlijke regelgeving.' This principle is a benchmark used in making laws. Vlies $^{9}$ is of the opinion that there are ten principles that need to be taken into consideration when drafting any bill. ${ }^{10}$ Those principles are: the principle of clarity in the objective (Het beginsel van de duidelijke doelstelling); the principle of the right organ (Het beginsel van het juiste organ); the necessity principle (Het

\footnotetext{
IC v.d.Vlies, Handboek Wetgeving, in HAS. Natabaya, Sistem Peraturan Perundang-Undangan Indonesia, Penerbit Sekretariat Jenderal dan Kepanitiaan Mahkama Konstitusi, Penerbit Sekretariat Jenderal dan Kepanitiaan Mahkamah Konstitusi, 2006, pp 33-38.

10 The ten principles above is adopted in The 2004 Law No. 10 on The Formation of Legislation (Pembentukan Peraturan Perundang-Undangan).
} 
noodzakelijkheids beginsel); the principle of practicality (Het beginsel van de uitvoerbaarheid); the principle of consensus (Het beginsel van consensus); the principle of clear terminology and clear systematic (Het beginsel van duidelijke terminologie en duidelijke sistematiek); the principle of accountability (Het beginsel van de kenbaarheid); the legal equivalent principle (Het rechtsgelijkeheidsbeginsel); the principle of legal certainty (Het rechtszekerheidsbeginsel) and the principle of individual justice (Het beginsel van de indivuduile rechtsbedeling). The ten principles above are therefore summarized by Natabaya ${ }^{11}$ into seven principles which include the principle of clear objectives, the principle of the right organ, the principle of suitability, the principle of enforceability, the principle of efficient and effective, the principle clarity in definition, and the principle of openness. ${ }^{12}$

In reality, many laws and regulations are drafted not in accordance with the principles above. The political needs are the characteristic of such law when produced. As a result, many laws and regulations cannot be spelled; profit orientation is more dominance than protecting the people or the community. For example, the Bankruptcy Law is more entrepreneurs pro. There are several parameters to measure the effectiveness of the law, such as the regulation itself, legal enforcers, legal apparatuses, and the legal culture of the people. Unfortunately, in terms of whether or not those parameters do not work in society, it is then very difficult to trace it down. The only method to exam-

11 HAS. Natabaya, Sistem Peraturan Perundang-Undangan Indonesia, Penerbit Sekretariat Jenderal dan Kepanitiaan Mahkama Konstitusi, 2006, pp 34-35.

12 See also: Achmad Romsan, "Environmental Human Rights: Problems of Implementation in Indonesia," a Ph.D. Thesis, Faculti Undang-Undang, Universiti Kebangsaan Malaysia, 2015. ine the parameters of law enforcement is through the reaction of the community. Under this situation, it seems the law develops slower than the development of the society. Furthermore, if the law is too progressive there will be many ineffective legal products and the public's reaction will be more frequent to happen. Thus, herein, national stability is considered more important than the law enforcement itself.

\section{Trade Dispute Settlement at the Com- mercial Court}

The existence of the Commercial Court as a Special Court under the General Courtis based on the Article 299 of the Regulation No. 37 of 2004 concerning Bankruptcy. This Article declares that "Unless otherwise stipulated in this Law, the applicable procedural law is a civil procedure law". The phrase "unless otherwise specified" according to the writer may mean that the processes of the dispute will be settled at the Commercial Court if the law has specifically determined the legal provisions of civil proceedings, in general, can be ruled out. Thus there can be differences in the proceedings at the Commercial Court as long as it has been determined by law. Other things include in the issue of limited competency of the Commercial Court, among others, concern the competency of the court; the exemption from mediation obligation and the specific time period in each process. The following will be the explanation of each issue.

\section{The Competence}

Under the Bankruptcy Law of 2004, the competency of the Commercial Court is to examine the dispute in the field of commerce, Intellectual Property Rights and the disputes over the Right to Industrial Design (Law No. 31 of 2000), disputes over the rights of Layout of Integrated Circuits (Law 
No. 32 of 2000), disputes concerning $\mathrm{Pa}-$ tents, (Law No. 14 of 2001), Trademark disputes (Law No. 15 of 2001); Copyright disputes (Law No. 28 of 2014).

\section{Exempt from mediation obligations}

The thing one should know that adjudicating commercial dispute to the Commercial Court has some advantages compared to the District Court. This is because the principles of fast, time saving and cheap are the characteristic of the Commercial Court. These principles even adopted from those of principles in the mediation but it is not the same as that of steps taken by the disputants in the mediation processes. ${ }^{13}$ Thus, the procedures employed in the Commercial Court will eliminate all the formalities as they are used in the District Court and in the mediation as well. The function of the judgment herein is only encouraged the disputants to reconcile. In other words, if the parties do not agree to reconcile, the judges then directly proceed to the examination of the dispute.

\section{The specific time period in each pro- cess}

At the Commercial Court, the proceedings process is fast and has been guaranteed by law. This can be observed when the process is in progress. Some procedures in the mediation and in the District Court have been simplified, such as the obligation of the disputants to mediate, no legal remedies and the duration of settling the dispute has been shortened by the law. The period of proceedings at the Commercial Court has been determined by the law otherwise the extension of time will be required by the approval from the Chairperson of the Supreme Court.

See Achmad Romsan, Alternative Dispute Resolution: Teknik Penyelesaian Sengketa di Luar Pengadilan, Negosiasi dan Mediasi, Malang: Intrans Publisher, 1916.

\section{CONCLUSION AND SUGGESTIONS}

\section{Conclusion}

Based on the previous analysis and discussion, the following is the conclusion:

1. The multifunction of the Commercial Court in adjudicating the case relating to bankruptcy, intellectual property rights (IPR), Islamic financing disputes has resulted in the need of having law that limits the competency of the Commercial Court.

2. The Competency Limitation of the Commercial Court in the Disputes Settlement, philosophically and constitutionally is based on the separation of powers and/or the division of powers affirmed in the Indonesian constitution. The commercial court as a sub-system in the judicial power has limited authority with different characteristics of authority as that of the General Court.

3. The authority of the Commercial Court is normally spread out to several new Indonesian regulations; inter alia, the regulation of Bankruptcy and the Postponement of Obligations to Pay Debt, the regulation on Intellectual Property Rights (IPR), and regulations regarding the Deposit Insurance Corporation. Restrictions on the authority of the Commercial Court are supported by an integrated component that is an integral part of the commercial court, including supervisory judges, curators, and other related parties.

4. The limitation concept of the Commercial Court competency in Indonesia to the judicial authority in resolving commercial disputes can be determined through ideal concepts such as: law enforcement, the total enforcement, and full enforcement. 
5. Differentiating indicators in the concept of limiting the authority of the commercial court are legal subjects proposing a commercial dispute settlement which will determine which court has the competence, for example, Islamic banking or Islamic insurance company, the religious court has the authority to examine, hear, and decide on the commercial dispute.

\section{Suggestions}

Based on the above conclusions, the following are the suggestions:

1. There needs to be a synchronization of a comprehensive understanding of bankruptcy laws and postponement of debt payment obligations, regulations on intellectual property rights and regulations on deposit insurance institutions. This synchronization is needed in an effort to give space to judges in an effort to deal with the resolution of disputes in the field of commerce more quickly, easily and simply as well as this is needed to strengthen the handling of dispute resolution in the field of commerce.

2. There needs to be a law on the commercial court specifically which is full in nature and regulates the commercial court which gives the judge broad authority in handling commercial cases. In handling commercial cases, it is still partial and has not met the expectations for people who need justice in the field of commerce. In handling this commercial case, the judiciary still faces obstacles, especially with regard to the competencies that deal with it so that the limits of authority with the existence of the law are clearer and stricter in its resolution.

\section{REFERENCES}

\section{Books}

Natabaya, HAS. 2006. IC v.d.Vlies, Handboek Wetgeving. Sistem Peraturan Perundang-Undangan Indonesia. Penerbit Sekretariat Jenderal dan Kepanitiaan Mahkamah Konstitusi.

Natabaya, HAS. 2006. Sistem Peraturan Perundang-Undangan Indonesia. Penerbit Sekretariat Jenderal dan Kepanitiaan Mahkamah Konstitusi.

Romsan, Achmad. 2016. Alternative Dispute Resolution: teknik Penyelesaian Sengketa di Luar Pengadilan, Negosiasi dan Mediasi. Malang: Intrans Publisher.

Romsan, Achmad. "Environmental Human Rights: Problems of Implementation in Indonesia," a Ph.D. Thesis, Faculti UndangUndang, Universiti Kebangsaan Malaysia, 2015.

Sumarmi. 2014. Perbandingan Sistem Hukum Kepailitan Antara Indonesia (Civil Law System) dengan Amerika Serikat (Common Law System). Medan: Fakultas Hukum Universitas Sumatra Utara.

\section{Regulations}

The 2009 Law No. 48 on the Judicial Power.

The 2004 Law No. 37 on the Bankruptcy and the Delay in Debt Repayment Obligations (State Gazette No. 131 of 2004.

HIR (State Gazette No. 16 of 1848).

RBG (Rechtreglement voor de Buitengewesten) State Gazette 1927 No. 227.

The 2004 Law No. 10 on the Formation of Legislation (Pembentukan Peraturan Perundang-Undangan) 